\title{
Polisi Syariah: Keamanan untuk Siapa?
}

\section{Haryanto}

\begin{abstract}
This paper is about community policing under Islamic Shari'a and its position in human security. This paper is intended to explain the characteristics and security paradigm in case Wilayatul Hisbah (Shari'a Police) in the province of Aceh. This paper connects the Shari'a police presence to human security, as well as how the characteristics of the security actors associated with maintaining order in the society of Aceh (community policing) are. As a result, the security paradigm in Aceh province is defined as the locality value, contradictory to those offered in the human security - to be adopted in a democratic transition regime as in Indonesia.
\end{abstract}

\section{Keywords:}

shari'a; human security; community policing.

\begin{abstract}
Abstrak
Tulisan ini tentang community policing di bawah Syariat Islam dan posisinya dalam human security. Tulisan ini dimaksudkan untuk menjelaskan karekteristik dan paradigma keamanan dalam kasus Wilayatul Hisbah (Polisi Syariah) di Provinsi Aceh. Untuk itu tulisan ini menghubungkan hadirnya Polisi Syariah dengan human security, serta bagaimana karekteristik dari aktor keamanan tersebut terkait dengan menjaga ketertiban dalam masyarakat Aceh (community policing). Hasilnya, paradigma keamanan di Provinsi Aceh dimaknai sebagai nilai lokalitas, kontradiktif dengan yang ditawarkan dalam human security - untuk diadopsi dalam rezim transisi demokrasi seperti di Indonesia.
\end{abstract}

\section{Kata kunci:}

syariah; keamanan manusia; polisi masyarakat.

\section{Pendahuluan}

Belakangan ini, topik keamanan menarik untuk diperbincangkan lagi. Alasannya, menghadapi ASEAN Community 2015, Indonesia masih memiliki sejumlah pertanyaanpertanyan mendasar dalam politik keamanan. Sejumlah negara ASEAN termasuk Indonesia dengan giatnya menyelenggarakan seminarseminar untuk mengkampanyekan isu seputar keamanan dengan konsep human security-nya. Mungkin, semua telah mahfum akan pentingnya konsep human security dalam hubungan antarnegara ASEAN. Karena paradigma human security sebagai isu global telah mampu "memaksa" studi-studi keamanan di seluruh dunia. Meningkatnya isu-isu non-militer yang serius seperti krisis keuangan Asia, kebakaran hutan di Indonesia, bom Bali, wabah SARS dan flu burung, tsunami, gempa bumi, banjir, perusakan hutan, dan pemanasan global telah menarik perhatian tentang human security di kawasan ASEAN (Othman, 2009: 1042). Namun,

\footnotetext{
- Mahasiswa Pascasarjana Fisipol UGM Yogyakarta Email: harymusi@gmail.com
} 
dalam level lokal di Indonesia, persoalan ini tak menemukan titik temu. Salah satunya paradigma keamanan dalam masyarakat Aceh yakni dengan hadirnya Wilayatul Hisbah atau Polisi Syariah.

Keberadaan Polisi Wilayatul Hisbah di Provinsi Aceh adalah salah satu contoh dari hadirnya aktor keamanan sipil di luar lembaga negara yang ada secara nasional. Otonomi khusus yang diberikan kepada provinsi Aceh adalah asal mula hadirnya lembaga Polisi Syariah di daerah tersebut. Kewenangan di bidang hukum dan politik yang dimiliki oleh provinsi yang dijuluki serambi Mekkah ini, telah memberikan kekuasaan yang lebih bagi pemerintah daerah untuk membentuk lembaga dengan fungsi keamanan - menjaga ketertiban (policing) - berdasarkan nilai lokalitas dan kepentingan politik yang endemik. Salah satunya, pemberlakuan Syariat Islam bagi masyarakat Aceh telah mendorong pemerintah membentuk community policing berdasarkan agama.

Kasus Polisi Syariah ini akan menuntun kita pada pertanyaan mendasar: apa yang hendak diamankan, kenapa harus diamankan, dengan apa hendak diamankan, serta bagaimana mengamankan? Pada akhirnya, keamanan untuk siapa? Tulisan ini memberikan batasan pada pertanyaan mengapa dan bagaimana lembaga ini terbentuk. Sehingga berdasarkan temuan dari pertanyaan ini, akan dianalisis secara konseptual bahwa keamanan dalam konsep lokal di Indonesia telah bersinggungan cukup jauh dalam konsep keamanan teorisasi Barat.

Mengapa kasus ini menarik? Pertama, sejumlah studi telah menunjukkan bahwa community policing berdasarkan afiliasi agama bukanlah carauntukmeringankan kekhawatiran - ancaman keamanan - bagi individu, di mana lembaga community policing adalah profesi yang sangat politis diresapi oleh kepentingan tertentu (Haberfeld, dikutip dalam Hakeem et al., 2012). Tesis tersebut akan dianalisis kembali dengan kasus dalam tulisan ini. Kedua, kehadiran Polisi Syariah di Provinsi Aceh telah menimbulkan pro dan kontra. Mereka yang kontra beranggapan, Polisi Syariah telah melanggar supremasi HAM, ide dan realita pelaksanaannya dianggap menghilangkan kebebasan individu serta menimbulkan rasa takut (Human Rigts Watch). Sedangkan mereka yang pro beranggapan bahwa kehadiran Polisi Syariah bertujuan menciptakan keamanan dan ketertiban dalam penegakan syariat Islam di Provinsi Aceh, sebagaimana termuat dalam Qanun. ${ }^{1}$ Dari perdebatan tersebut, temuan konseptual terhadap paradigma keamanan akan diajukan sebagai bagian dari kesimpulan tulisan ini.

\section{Paradigma Human Security dan Community Policing}

Human security dalam pengertiannya secara luas termasuk keamanan umum, keamanan global, maupun kerjasama keamanan sebagai sesuatu yang lebih dari pertahanan militer dan kepentingan wilayah sebuah negara (Paris, 2001). Definisi human security tersebut bervariasi atau bahkan sangat luas dan kabur, namun sebagian besar rumusan ini menekankan pada kesejahteraan individu. Telah disimpulkan bahwa human security adalah perkembangan teoretis dari pemaknaan keamanan "tradisional" yang sebelumnya menyangkut keamanan negara atau biasa disebut national security, yang kemudian berkembang pasca perang dingin setelah adanya publikasi Human Development Report tahun 1994 oleh United Nations Development Programme (UNDP). Konsep tradisional tentang keamanan yang state-centred kemudian melintasi ruang dan waktu menjadi peoplecentred (Shinoda, 2004: 5-7). Singkatnya, keamanan yang dalam arti politik berarti

\footnotetext{
1 Qanun adalah Peraturan Perundang-undangan sejenis Peraturan Daerah yang mengatur penyelenggaraan pemerintahan dan kehidupan masyarakat di Provinsi Aceh.
} 
perlindungan negara dari ancaman eksternal, menjadi keamanan lebih dari arti melindungi negara, melainkan termasuk keselamatan individu dari kekerasan atau kejahatan, perdamaian, HAM, dan tindakan untuk mempertahankan standar hidup tertentu.

Dalam laporan UNDP disebutkan bahwa ide human security pada dasarnya bertujuan untuk merevolusi masyarakat di abad 21, dengan konsep dasar yang harus fokus pada empat karakteristik esensialnya (UNDP, 1994: 22-23). Pertama, human security merupakan keprihatinan universal. Hal ini diklaim relevan untuk masyarakat di manapun, di negara-negara kaya dan miskin. Ada banyak ancaman yang umum bagi semua orang, seperti pengangguran, narkoba, kejahatan, polusi dan pelanggaran hak asasi manusia. Kedua, komponen human security harus saling bergantung. Ketika rasa aman orang terancam di setiap tempat di dunia, semua negara kemungkinan besar untuk ikut terlibat. Kelaparan, penyakit, polusi, perdagangan narkoba, terorisme, perselisihan etnis dan disintegrasi sosial adalah peristiwa yang tidak lagi terisolasi, terkurung dalam batas-batas nasional. Konsekuensinya human security mengelilingi dunia. Ketiga, human security di klaim lebih mudah untuk menjamin keamanan melalui pencegahan dini. Hal ini memberikan biaya yang murah untuk mencegah ancaman di hulu daripada di hilir. Terakhir, human security adalah people-centred. Hal ini berkaitan dengan bagaimana orang-orang hidup dan "bernapas" dalam masyarakat, bagaimana mereka beraktivitas dengan bebas dengan banyak pilihan, berapa banyak akses yang mereka miliki terhadap peluang pasar dan sosial, dan apakah mereka hidup dalam konflik atau damai.

Dalam laporan tersebut disebutkan pula tujuh elemen khusus yang membentuk human security (UNDP, 1994: 24-25; Paris, 2001: 90) yakni:(1) economic security (terjamin penghasilan dasar); (2) food security (akses fisik dan ekonomi terhadap pangan); (3) health security (akses ke perawatan kesehatan dan perlindungan dari penyakit); (4) environmental security (perlindungan dari bahaya seperti pencemaran lingkungan; (5) personal security (keselamatan fisik dari hal-hal seperti penyiksaan, perang, serangan kriminal, kekerasan dalam rumah tangga, penggunaan narkoba, bunuh diri, dan bahkan kecelakaan lalu lintas); (6) community security (keamanan identitas budaya); dan (7) political security (pemenuhan hak-hak asasi manusia dan kebebasan). Berdasarkan laporan tersebut, konsep human security kemudian menjadi topik yang hangat dibincangkan dan dikutip oleh para pengambil kebijakan maupun akademisi (Paris, 2001: 90). Konsep ini telah mampu untuk mengaitkan segala hal dengan alasan keamanan. Menurut Hideaki Shinoda, konsep human security berarti melindungi kebebasan secara fundamental - kebebasan yang merupakan esensi kehidupan - yang melindungi individu dari ancaman segala hal dan situasi apapun, sehingga konsep ini telah menciptakan sistem politik, sosial, lingkungan, ekonomi, militer dan budaya yang bersama-sama memberi bangunan terhadap kelangsungan hidup, mata pencaharian dan martabat manusia (Shinoda, 2004: 14). Singkatnya, human security - dalam artian individu - adalah sesuatu yang suci dan tidak bisa diganggu gugat.

Akan tetapi, menurut Roland Paris, konsep ini begitu luas dan akan sulit untuk diterjemahkan secara empirik oleh para peneliti studi keamanan. Untuk itu, Paris menawarkan sebuah kategori penelitian studi keamanan untuk mempersempit dan mempermudah definisi tentang human security kedalam sebuah matriks (Paris, 2001: 98). Roland Paris menawarkan sebuah kerangka kerja penelitian bagi policy makers atau akademisi yang ingin menjelaskan human security, sebagai label untuk sebuah kategori yang sangat luas dalam bidang studi keamanan yang terutama berkaitan dengan ancaman non-militer dengan keselamatan masyarakat, kelompok, dan 
Matriks Studi Kemanan (Paris, 2001: 98)

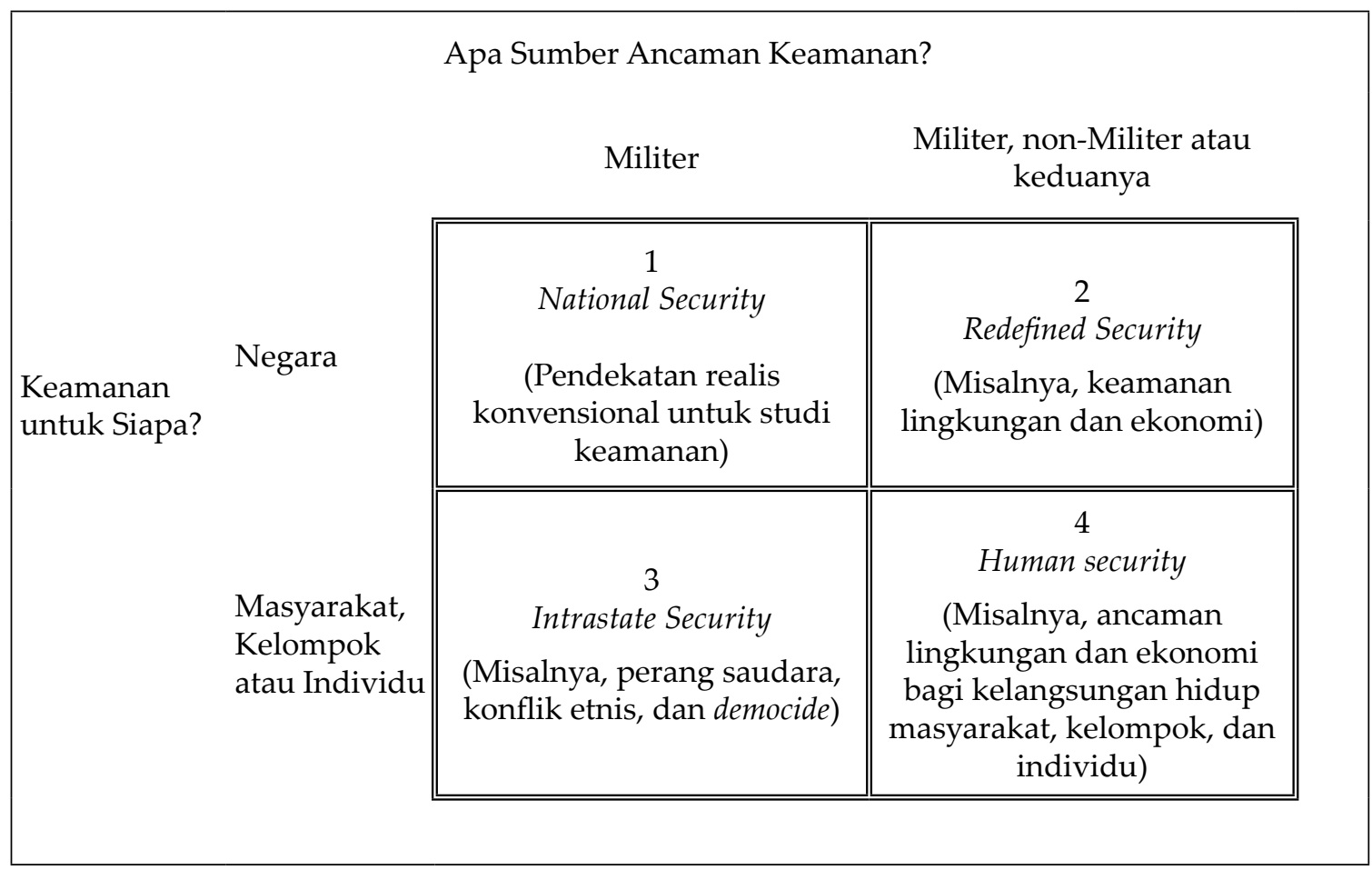

individu, berbeda dengan lebih banyak pendekatan tradisional untuk penelitian keamanan yang fokus pada melindungi negara dari ancaman eksternal. Pengkategorian penelitian tersebut tergambar dalam matriks yang dibagi dalam empat kotak.

Matriks tersebut masing-masing mewakili sekelompok penulisan yang berbeda di lapangan, dengan dasar bahwa ancaman keamanan adalah konotasi beberapa jenis ancaman bagi kelangsungan hidup manusia. Bagian atas matriks mencakup penelitian yang berfokus pada ancaman keamanan negara, sedangkan bagian bawah adalah yang berfokus pada ancaman keamanan bagi masyarakat, kelompok, dan individu. Sisi kiri dari matriks menunjukkan literatur yang berfokus pada ancaman militer, sedangkan sisi kanan pada ancaman militer atau nonmiliter, atau keduanya. Sementara itu, Zarina Othman (2009: 1043) menyebutkan bahwa literatur human security di kawasan Asia dapat dikategorikan menjadi tiga kelompok: 1) individu sebagai objek keamanan; 2) teori sistem dunia, termasuk globalisasi sebagai ancaman dalam human security; dan 3) ancaman terhadap human security yang berasal dari dalam negara itu sendiri.

Disisi lain, akibatnya human security telah menjadi konsep sentral dalam memahami dan mengimplementasikan keamanan dalam berbagi aspek, termasuk policing. Lahirnya konsep human security secara tidak langsung menimbulkan perdebatan paradigma kepolisian yang sama, state-centred atau peoplecentred. Pergulatan paradigma dalam upaya peletakan polisi sebagai proses terbagi dalam dua hal (Hiariej et al., 2012). Pertama, posisi polisi dalam paradigma negara yang mengacu pada paradigma state security. Paradigma ini meletakkan polisi sebagai institusi yang memperkuat state building dan penjaga rezim. Dikenal istilah negara polisi (police state), polisi politik (political police), dan polisi yang dimiliterkan (militarized police). Kedua, posisi polisi dalam paradigma masyarakat atau people security. Orientasi pelembagaan polisi dalam paradigma ini dimaksudkan bukan untuk melayani regime atau state melainkan untuk 
melayani warga. Dalam paradigma ini dikenal istilah polisi sipil (civilian police), pemolisian demokratik (democratic policing), pemolisian komunitas (community policing) dan pemolisian kolektif (collective policing).

Berdasarkan konsepsi di atas, posisi lembaga Polisi Syariah termasuk dalam istilah pemolisian komunitas (community policing) yang berorientasi pada people-centred (human security). Akan tetapi, ketika ditelisik lebih jauh, kesimpulan berbeda akan kita temukan-uraian ini akan dijelaskan pada bagian selanjutnya. Sebelumnya, ada baiknya kita memahami apa yang dimaksud dengan community policing.

Belakangan ini, community policing adalah tren terbaru dari lembaga polisi di berbagai negara, yang berorientasi pada prinsip proaktif dan antisipatif, dengan menekankan strategi preventive dan melakukan kerja sama dengan berbagai stakeholders (Siboro, 2008: 235). Di Indonesia tren tersebut dikenal dengan nama pemolisian masyarakat (Polmas). Salah satu pengertian community policing yakni didefinisikan sebagai filosofi perpolisian yang dirancang untuk mengurangi kejahatan dan gangguan di masyarakat dengan meningkatkan kepercayaan, rasa hormat, dan kolaborasi antara polisi dan warga negaranya (Nicholl, 1999: 24). Sementara itu, definisi klasik menurut Robert K. Manning (1984), community policing dapat dijelaskan dalam beberapa poin (dikutip dalam Garba, 2013). Pertama, community policing adalah "ideological system", didasarkan pada keyakinan bahwa kejahatan di masyarakat dapat diurus melalui kerjasama polisi dan masyarakat untuk menggunakan kontrol sosial yang lebih luas. Kedua, community policing berarti sebuah program yang memiliki maksud politik untuk mengembalikan hubungan antara polisi dan warga negara dan mengurangi rasa takut bagi kejahatan di masyarakat. Ketiga, community policing merupakan tuntutan pragmatis, karena menanggapi ketidakpuasan warga negara dengan "polisi yang birokratis dan impersonal". Keempat, berfokus pada struktur organisasi, yang meliputi unsur-unsur: (1) bekerja di daerah tertentu sebagai sebuah tim; (2) partisipasi dan berkomunikasi dengan masyarakat; (3) berusaha untuk memberikan dukungan organisasi dan manajerial keamanan bagi lembaga polisi.

Berdasarkan definisi di atas, Ahmed S. Garba (2013) menyebutkan bahwa community policing mendorong dan mendukung strategi organisasi yang ditujukan pada penyebab dan mengurangi ketakutan akan kejahatan dan gangguan sosial melalui strategi pemecahan masalah dan kemitraan antara masyarakat dan polisi. Community policing adalah perubahan mendasar dari kebijakan tradisional yang reaktif, menekankan pemecahan masalah melalui masyarakat yang proaktif. Garba juga meneliti hubungan community policing dan syariat Islam di Nigeria, menurutnya, Islamic Institution of Hisbah secara lembaga dibentuk untuk membatu kerja-kerja pemolisian yang dilakukan oleh polisi, namun tidak sampai pada proses pengadilan, dan lebih cenderung mengawasi dan mencegah kemungkinan adanya gangguan keamanan dan ketertiban.

Di Indonesia, community policing terbagi dalam duabentuk, yakni dibawahi langsungoleh Polri, dan yang lain dibawahi oleh pemerintah (misalnya Gubernur atau Bupati/Walikota). Sebelumnya, Polri telah mengembangkan community policing secara tradisional yakni program bimbingan masyarakat (Bimmas) dan program yang berkaitan dengan sitem keamanan swakarsa (Siskamswakarsa) yang dilakukan melalui sistem keamanan lingkungan (Siskamling), termuat dalam UU Polri Nomor 2/2002 (Siboro, 2008: 260). Saat ini, disebutkan bahwa tugas Polmas berdasarkan ketentuan Polri (Surat Keputusan Nomor Pol: SKEP/433/ VII/2006 tentang Panduan Pembentukan dan Operasionalisasi Perpolisian Masyarakat) yakni menyelenggarakan fungsi deteksi berkaitan dengan kamtibmas setempat. Begitu pun yang dilakukan oleh pemerintah daerah, yang memiliki lembaga community policing atau biasa 
dikenal dengan istilah municipal police. Contoh dari lembaga ini yakni aparat Ketentraman dan Ketertiban (Tramtib) seperti Satpol PP dan Hansip. Keseluruhan dari lembaga-lembaga tersebut menggunakan dasar hukum formal sebagai paradigma keamanan dan ketertiban. Dalam kasus Polisi Syariah, ide dasar dari lembaga ini adalah Syariat Islam. Untuk itu, perlu juga dipahami konsep keamanan dalam logika Islam, dikarenakan konsep inilah yang kemudian digunakan sebagai landasan bagi Pemerintah Aceh melihat keamanan dengan membentuk lembaga community policing.

\section{Keamanan dalam Syariat Islam}

Pada hakikatnya Syariat Islam atau syariah adalah kode etik yang diikuti oleh umat Islam berdasarkan dua sumber rujukan utama yakni Alquran dan Sunnah Nabi, selain dari sumber lain yakni ljma (konsensus) dan Qiyas (penalaran analogis). Syariah menetapkan aturan hukum untuk membimbing manusia menuju perbuatan baik (Ma'ruf) dan meninggalkan kejahatan (Munkar). Singkatnya, syariah bertujuan untuk mendorong kesuksesan dan kesejahteraan umat manusia baik dalam kehidupan di dunia dan di akhirat. Syariah mengacu pada totalitas perintah agama, dan memberikan kedudukan tertinggi untuk evaluasi pada ketentuan agama, dari seluruh urusan kehidupan seharihari dalam bermasyarakat. Selain itu, agama menjadi ketentuan untuk melarang atau melakukan sesuatu yang diperbolehkan dalam hukum. Secara teoritik, syariah terdiri dari perintah-perintah yang telah jelas dari Alquran, aturan-aturan yang diperkenalkan melalui praktek Nabi, dan pendapat para ahli figh atau hukum (Effendy, 2011; Hakeem et al., 2012).

Farrukh B. Hakeem, M.R. Haberfeld dan Arvind Verma (2012: 9-10) merangkum pengertian Syariat Islam terkait dengan keamanan dalam beberapa definisi yang telah diajukan oleh beberapa akademisi. Pertama, dalam aspek hukum, syariah berbeda dari sistem hukum Barat atas dasar ruang lingkup dan konsepsi hukum, dimana syariah mencakup semua tugas agama yang mengatur kehidupan setiap orang Islam dalam segala aspek. Kedua, Syariah bukan hanya sistem hukum, tetapi juga kode etik yang komprehensif yang meliputi domain publik dan kegiatan individu. Berbeda dengan sistem lain, syariah beroperasi dalam domain internal dan eksternal dari individu (batiniah dan hubungan sosial), melalui interaksi ritual, keyakinan, tindakan, dan kesadaran masyarakat, sehingga individu tersebut berusaha untuk dikendalikan. Ketiga, pemerintah atau otoritas lain diperlukan untuk bertindak demi kepentingan umum untuk melindungi lima aspek dasar ini kehidupan sosial yakni kehidupan sosial, pikiran (reputasi atau perasaan individu), agama, kepemilikan, dan keluarga. Syariah menganggap pelanggaran terhadap salah satu dari ini tidak dibenarkan. Ini melukiskan tujuan, mekanisme, dan teknik yang digunakan oleh syariah adalah untuk menjaga keamanan masyarakat.

Terkait dengan pandangan Islam tentang keamanan manusia yakni menyangkut penghidupan dan kebutuhan-kebutuhan hidup manusia, yang dipahami dalam konteks pemberian kedaulatan oleh agama kepada manusia melalui kekhalifahan adalah untuk menjalankan fungsi-fungsi keamanan (Imarah, 1999: 40-1). Menurut Muhammad Imarah, khalifah dalam pengertian Islam berarti "pengganti", bermakna mengatur manusia atas penghidupan dan kebutuhankebutuhan hidupnya di dunia. Dengan pengertian kekhalifahan seperti inilah Islam melihat kedudukan manusia sebagai makhluk yang mengemban tugas kekhalifahan, yang mendapatkan wewenang untuk membangun kehidupan di dunia, dan yang mempunyai kehendak untuk mengambil tindakan dalam batasan kewenangannya itu. Namun demikian, kehendak bebas dan inisiatifnya itu harus tunduk dengan aturan-aturan dan batasanbatasan kewenangan tugas kekhalifahan 
atau Syariat Islam sebagai rambu-rambu, aturan, batasan dan scope operasional tugas perwakilan dan amanah kekhalifahan itu. Singkatnya, khalifah atau negara menjadi penentu bagaimana keamanan manusia ditafsirkan dan dipraktekkan berdasarkan ketentuan-ketentuan yang ada di dalam agama.

Berdasarkan hal tersebut di atas, maka dalam sistem Syariat Islam dibentuk sebuah lembaga Hisbah yang merupakan bagian integral dari skema sosial ekonomi Islam dan kepolisian. Fungsinya adalah menjaga hukum dan ketertiban umum serta mengawasi perilaku pembeli dan penjual di pasar. Maksud dari Syariat Islam adalah menjamin pelaksanaan hak masyarakat dan perlindungan mereka dari ketidakjujuran dan malpraktek; sedangkan tujuan dari dibentuknya Syariat Islam itu sendiri adalah mengatur kehidupan publik sedemikian rupa sehingga derajat moralitas publik yang tinggi tercapai, dan masyarakat dilindungi dari perbuatan yang buruk, penipuan, pemerasan, eksploitasi, dan penipuan (Ahmad dikutip dalam Olaniyi, 2011: 75). Dalam konteks Aceh, birokrasi Syariah saat ini terdiri dari sejumlah badan yang berbeda tapi saling terkait (Feener, 2012: 277). Dalam sistem ini terdapat Dinas Syariat Islam (DSI), yang pengoperasiannya bekerja dengan lembaga-lembaga utama lain yang terlibat dengan pelaksanaan Syariat Islam di Aceh, yakni, Pengadilan Syariah (Mahkamah Syariah/MS), Majelis Ulama (Majlis Permusyawaratan Ulama/MPU), dan Polisi Syariah (Wilayatul Hisbah/WH).

Namun demikian, dewasa ini konsep maupun konteks syariah telah mengalami pembiasan, menyimpang danjauh dari substansi syariah itu sendiri. Peneliti meyakini bahwa hal ini, tidak terlepas dari interpretasi terhadap makna-makna dibalik dasar hukum syariah yang berbeda-beda. Misalnya dalam konteks Indonesia, menurut Wasisto R. Jati, memahami syariah sebagai produk hukum, hakikatnya adalah memahaminya sebagai produk politik, sehingga karakter substansi produk hukum sangat dipengaruhi oleh konfigurasi politik yang melahirkannya. Ummat berkembang menjadi objek strategis seiring dengan diberlakukannya hukum, dan perkembangan ini sangatlah erat dengan kepentingan kekuasaan. Maka tidak mengherankan, apabila hukum merupakan manifestasi cara rezim berkuasa memperlakukan rakyatnya (Jati, 2013: 307).

\section{Aceh: Agama, Adat dan Keamanan}

Dalam berbagai literatur tentang Aceh, disebutkan bahwa agama banyak memengaruhi aspek kehidupan masyarakatnya (Hasjmy, 1983; Ismuha, 1983; Sufi dan Wibowo, 2006). Agama Islam telah menjadi fondasi kehidupan bermasyarakat, sosial, ekonomi, politik, tata negara, hukum dan budaya; bahkan banyak yang mengatakan rakyat Aceh sangat fanatik terhadap agama Islam. ${ }^{2}$ Untuk itu, pada bagian ini, akan dicoba melihat bagaimana pengaruh Islam dan adat sebagai fondasi politik keamanan dalam masyarakat Aceh.

Pengaruh Islam dalam masyarakat Aceh terlihat pada barometer atas segala sikap, perbuatan dan penampilan mereka dalam pergaulan sesamanya. Sikap dan pandangan tersebut misalnya menyangkut benar-salah, bagus-jelek, dan baik-buruk selalu dikaitkan dengan ajaran Islam (Sufi dan Wibowo, 2006: 1-2). Pada akhirnya, penghayatan yang begitu besar dan mendalam terhadap ajaran Islam diwujudkan dalam bentuk akulturasi antara adat dengan ajaran agama (Pha, dikutip dalam Sufi dan Wibowo, 2006: 1). Hal ini berarti bahwa seseorang yang telah berperilaku dan

\footnotetext{
Fanatik adalah istilah lain dari pada taat, namun seorang yang fanatik belum tentu taat. Kalau kita katakan mereka (masyarakat Aceh) tidak Islam, mereka marah betul dan matipun mereka mau, tetapi belum tentu semua mereka shalat dan puasa (lihat Ismuha, 1983, "Ulama Aceh dalam Perspektif Sejarah", dalam Taufik Abdullah (ed.), Islam dan Perubahan Sosial, hlm. 7).
} 
bersikap sesuai dengan yang dituntut atau digariskan dengan adat, maka hal itu berarti ia telah berperilaku dan bersikap sesuai dengan ajaran agamanya, atau sekurang-kurangnya tidak keluar dari bingkai agama yang mereka anut. Oleh karena itu, Islam menjadi semacam falsafah kehidupan yang dilegalisasi dalam bentuk adat (Sufi dan Wibowo, 2006: 2). Singkatnya, antara agama dan adat adalah satu kesatuan, ketika berbicara agama maka itulah adat, begitupun sebaliknya. Seperti yang termuat dalam falsafah berikut ini (Ismuha, 1983: 6; Sufi dan Wibowo, 2006: 2):

"Adat bak Poteumeurohom, Hukom bak Syiah Kuala, Kanun bak Putro Phang, Reusam bak Laksamana, ...Hukom ngon Adat lagee dzat ngon sipheuet, ... Hukum ngon Adat hanjeuet cree, lagee mata itam ngon mata puteh". ${ }^{3}$

Dalam aspek keamanan, pengaruh Islam tampak jelas pada sejarah perlawanan masyarakat Aceh, sejak perlawanan terhadap kolonialisme Belanda hingga perlawanan terhadap Republik Indonesia. Paradigma agama sebagai security oriented, menjadi salah satu bagian dalam sejarah politik keamanan di Aceh. Sebagai contoh, PUSA (Persatuan Ulama Seluruh Aceh) yang berdiri pada tanggal 5 Mei 1939, diketuai oleh Daud Beureuh, yang pada awalnya sebagai wadah untuk memurnikan agama Islam kemudian menjadi cikal bakal gerakan perlawanan terhadap Belanda (Saleh, 1992: 17-18). ${ }^{4}$ Mereka yang terlibat di dalamnya

\footnotetext{
3 Adat-hukum pengaplikasiannya dalam masyarakat berada di bawah tanggung jawab raja/pemerintahan, sedangkan hukum-hukum Islam berada di bawah tanggung jawab ulama, adat-istiadat dan upacara kenegaraan berada di bawah tanggung jawab Putro Phang, dan adat istiadat atau kebiasaan berada di bawah tanggung jawab penguasa-penguasa atau pemimpin-pemimpin setempat, ...hukum Islam dan hukum adat ibarat benda dengan sifatnya, jadi tidak dapat dipisahkan, ...hukum Islam dan hukum adat tidak boleh berpisah seperti mata hitam dan mata putih.

4 Peran Ulama (Islam) begitu dominan dalam berbagai
}

juga menjadi tokoh penting meletusnya pemberontakan Aceh 1953, hingga pada pemberontakan GAM yang dimulai dari tahun 1970-an sampai beberapa tahun belakangan ini. Selain itu, pada tahun 1962, telah dikeluarkan sebuah regulasi keamanan dengan judul “Keputusan Penguasa Perang, Nomor KPTS/ Peperda-061/26/1962 tentang Kebijaksanaan Pelaksanaan Unsur-Unsur Syariat Agama Islam Bagi Pemeluk-Pemeluknya di Daerah Istimewa Aceh", yang ditandatangani oleh M. Jasin, Panglima Daerah Militer I Aceh/Iskandar Muda pada saat itu; di sini, Islam menjadi foundation of security.

Terlebih lagi ketika membicarakan konflik yang berkepanjangan antara Pemerintah RI dengan gerakan-gerakan separatis di Aceh. Dimulai dari DI/TII sampai dengan GAM - paling tidak salah satunya - sulit untuk mengabaikan faktor agama dalam menjelaskan politik keamanan pada saat itu. Bahkan menurut Edward Aspinall, seandainya hukum (UU Otonomi Khusus) - salah satunya tentang Syariat Islam - seperti itu disahkan dan diimplementasikan pada tahun 1960 mungkin dapat mencegah radikalisasi yang dilakukan GAM (Aspinall, 2005: 4). Menurutnya lagi, Islam secara historis adalah salah satu faktor yang berkontribusi penting untuk konflik dan keamanan. Pada tahun 1950, tujuan utama dari DI/TII adalah penerapan hukum Syariat Islam, begitupun pada awal pemberontakan GAM sebagian menekankan tuntutan tentang Islam. ${ }^{5}$ Walaupun pasca Reformasi, Islam

permasalahan di Aceh. Disebutkan bahwa tidak dapat dipungkiri peranan yang begitu dominan dari para Ulama d Aceh, baik di era Kerajaan Samudera Pasai, Kerajaan Aceh Darussalam, kemerdekaan RI, peristiwa Cumbok, dan pemberontakan Darul Islam (lihat dalam Muliardi Kurdi (ed.) 2010, “Ulama Aceh”, hlm. 5). Begitupun dalam era Reformasi sekarang ini, salah satu isi dari Undang-Undang Otonomi Khusus Aceh memuat poin tentang peningkatan peran ulama dalam pemerintahan Aceh.

5 Menurut Ikrar Nusa Bhakti, GAM sebenarnya agak enggan mengimplementasikan Syariah Islam. Tetapi, jika mereka menentang penerapan syariah, mereka akan kehilangan dukungan dari masyarakat 
hanya memainkan peran sekunder, akan tetapi Pemerintah Indonesia justru bergerak untuk menggunakan aspek Syariat Islam sebagai strategi politik keamanan di Aceh (Aspinall, 2005: 4).

Pengaruh adat juga tertulis dengan jelas dalam UUPA yang mengatur tugas-tugas bidang pertahanan dan keamanan. Pasal 202 ayat 4 dalam undang-undang tersebut berisi keharusan bagi prajurit TNI untuk menjunjung prinsip universal Hak Asasi Manusia dan adat istiadat Aceh. UUPA juga mengatur tentang kepolisian pada pasal 204 sampai dengan pasal 207, beberapa diantaranya meliputi aturan tentang integrasi budaya dan syariat Islam dalam seleksi bintara dan perwira, dan penempatan bintara dan perwira kepolisian dari luar Aceh yang ditetapkan oleh Kapolri harus memperhatikan hukum, budaya dan adat istiadat yang berlaku di Aceh.

Kesimpulannya, uraian di atas menunjukkan bahwa Islam dan adat telah menjadi bagian dari kehidupan masyarakat Aceh, hingga Aceh dikenal dengan sebutan Serambi Mekkah. Perjalanan sejarah juga menunjukkan Islam dan adat tidak lepas dari aspek sosio-kultural masyarakat Aceh. Pada akhirnya agama dan adat menjadi karekteristik alamiah (indigenously) dalam menjelaskan politik, begitupun dalam keamanan. Karekteristik indigenously menjadi sentrum dalam memahami security, baik itu tentang perjuangan kemerdekaan, konflik, maupun resolusi perdamaian, yang mewarnai dinamika politik keamanan di Aceh. Namun demikian, pertanyaan selanjutnya adalah,

(http://www.politik.lipi.go.id/kolom/kolom-aceh/10problematika-keamanan-di-aceh-pasca-mou-helsinkidan-prospeknya-di-masa-depan.html). Sejak tahun 1990-an GAM tidak lagi mengadvokasi pelaksanaan hukum Islam, tetapi mendesak kemerdekaan dan pengakhiran pelanggaran-pelanggaran hak asasi manusia oleh aparat militer Indonesia dan menolak untuk menjelaskan lebih lanjut sistem hukum yang akan didukung oleh GAM dalam Aceh yang berdaulat (Damien Kingsbury dikutip dalam Human Right Watch, 2010: 17). apakah klaim agama dan adat sebagai peradaban ataupun struktur masyarakat tidak dapat dimanipulasi oleh aktor untuk kepentingan-kepentingan tertentu. Pada kontes ini, elit bisa saja menggunakan struktur untuk menstrukturkan masyarakat. Fakta ini rentan menimbulkan pertentangan dan konflik; misalnya pelembagaan terhadap agama melalui kebijakan dan peraturan yang menciptakan otoritas elit, namun pada praktiknya bersinggungan dengan disparitas keadilan di masyarakat. Peraturan tersebut hanya menyasar masyarakat bawah sementara tidak untuk elit. Pada gilirannya, masyarakat cenderung untuk defensif dan menolak aturan dan ketentuan dari pemerintah. Terlebih lagi jika otoritas tersebut dalam implementasinya disalahgunakan dan dilaksanakan dengan pendekatan yang keliru, berbeda dengan pola hidup yang selama ini menjadi habitual dan ritus di masyarakat. Memang Islam adalah fondasi sebagai nilai tetapi ritus bisa saja berbeda, karena sebagai tingkah laku, ritus seringkali dipengaruhi oleh banyak hal diluar nilai agama.

\section{Polisi Syariah: Latar Belakang, Definisi, Dasar Hukum, Kewenangan, dan Policing Function}

Latar belakang terbentuknya Polisi Syariah tidak bisa dilepaskan dari sejarah Aceh dan identitas ke-Islamannya. Dalam profil Polisi Syariah Provinsi Aceh, disebutkan bahwa pada awalnya, tuntutan tentang pelaksanaan Syariat Islam telah ada sejak negara Indonesia ini terbentuk. ${ }^{6}$ Diawali dari masa Orde Lama, permintaan kepada pemerintah pusat agar diberikan kewenangan untuk melaksanakan Syariat Islam pernah dilakukan; namun tidak dipenuhi. Lahirnya DI-TII di Aceh

\footnotetext{
6 Pada penjelasan selanjutnya dalam bagian ini, banyak dirangkum profil yang dimuat dalam website resmi Pemerintah Provinsi Aceh. Profil Polisi Syariah Aceh secara lengkap dapat dilihat di http://satpolppwh. acehprov.go.id/index.php/profil.html.
} 
sendiri adalah manifestasi kekecewaan dari masyarakat Aceh terhadap penolakan tersebut. Pada akhirnya, pada masa Orde Baru, Aceh diberikan keistimewaan dalam bidang agama, pendidikan, dan adat istiadat. Namun keistimewaan ini belum memenuhi aspirasi rakyat Aceh, karena berbagai alasan pembangunan dan politik. Hal ini kemudian memicu lahirnya Gerakan Aceh Merdeka (GAM). Baru pada masa transisi reformasi, rakyat Aceh diberi kewenangan menerapkan Syariat Islam yang seluas-luasnya.

Wujud dari permintaan rakyat Aceh pada saat itu adalah lahirnya Undang-Undang Nomor 44 tahun 1999 tentang Penyelenggaraan Keistimewaan Propinsi Daerah Istimewa Aceh, meliputi keistimewaan dalam bidang agama, pendidikan, adat istiadat, dan peningkatkan peran ulama dalam pemerintahan Aceh. Sebagai konsekuensi lahirnya undang-undang tersebut maka lahirlah Peraturan Daerah Nomor 5 Tahun 2000 tentang Pelaksanaan Syariat Islam. Dalam regulasi tersebut, pasal 20 ayat (1) menyebutkan bahwa "Pemerintah Daerah berkewajiban membentuk badan yang berwenang mengontrol atau mengawasi pelaksanaan ketentuan-ketentuan dalam Peraturan Daerah ini, sehingga dapat berjalan dengan sebaik-baiknya". Ketentuan ini merupakan dasar hukum lahirnya Polisi Syariah atau Wilayatul Hisbah di Provinsi Daerah Istimewa Aceh pada saat itu.

Pada awalnya, kedudukan Polisi Syariah disarankan untuk ditempatkan di lembaga Polisi Negara (Polri), namun Polri pada saat itu tidak menyetujui hal tersebut, sehingga mulai tahun 2000 sampai dengan 2001 Polisi Syariah masih sebatas wacana pemerintah saja. Kemudian pada tahun 2001, Undang-Undang Nomor 18 tahun 2001 tentang Otonomi Khusus sebagai Provinsi Nanggroe Aceh Darussalam mendasari lahirnya Qanun Nomor 11 tahun 2002 tentang Pelaksanaan Syariat Islam di bidang Aqidah, Ibadah, dan Syi'ar Islam. Kemudian Qanun Nomor 12 tahun 2003 tentang Khamar, Qanun Nomor 13 tahun 2003 tentang Maisir dan Qanun Nomor 14 tentang Khalwat/Mesum. Didalam keempat qanun tersebut, sangat jelas disebutkan fungsi dan tugas Polisi Syariah, namun demikian lembaga tersebut belum juga lahir. Selanjutnya, pada awal tahun 2004 lahirlah Keputusan Gubernur Nomor 1 tahun 2004 tentang Tata Kerja dan Struktur Organisasi Wilayatul Hisbah. Di dalam Keputusan Gubernur tersebut diamanatkan bahwa Wilayatul Hisbah berada di bawah Dinas Syariat Islam atau dibawah Pembinaan Sub Dinas Pengawasan Syariat Islam.

Pada perkembangan selanjutnya, pasca perjanjian Helsinki, lahirlah Undang-Undang Nomor 11 tahun 2006 atau Undang-Undang Pemerintahan Aceh (UUPA). Dalam pasal 244 ayat (1) disebutkan bahwa "Gubernur, Bupati/ Walikota dalam menegakkan ketertiban dan ketentraman umum dapat membentuk Polisi Pamong Praja", sedangkan dalam ayat (2) disebutkan bahwa "Gubernur, Bupati/walikota dalam menegakkan Qanun Syariah dapat membentuk Polisi Wilayatul Hisbah sebagai bagian dari Polisi Pamong Praja". Akhirnya, Pemerintah Aceh membuat Peraturan Gubernur Nomor 47 Tahun 2008 tentang Tugas Pokok dan Fungsi Satuan Polisi Pamong Praja dan Wilayatul Hisbah Provinsi Aceh. Berdasarkan ketentuan tersebut, cukupjelas bahwa Wilayatul Hisbah merupakan bagian dari Satuan Polisi Pamong Praja (Satpol PP), sebagai lembaga yang menegakkan Qanun Gubernur, Bupati/ Walikota di wilayah Pemerintahan Aceh dalam penyelenggaraan ketertiban umum dan ketentraman masyarakat, serta pelaksanaan Syariat Islam.

Adapun pengertian dari Wilayatul Hisbah secara etimologis berasal dari bahasa arab yang terdiri dari dua suku kata yaitu "wilayah" dan "hisbah". Ramzi Murziqin (2010: 14-7) menguraikannya dengan panjang lebar bahwa arti wilayah yakni lembaga yang diberi wewenang dan tanggung jawab oleh negara, untuk melaksanakan tugas kenegaraan 
tertentu sesuai dengan bidang tertentu. Dalam politik Islam, istilah wilayah bermakna wewenang dan kekuasaan, yang dimiliki oleh institusi pemerintahan untuk menegakkan jihad, keadilan, hudud, melakukan amar ma'ruf nahi mungkar, serta menolong pihak yang teraniaya. Sedangkan kata hisbah secara harfiah berarti jumlah, hitungan, hadiah dan pahala. Dalam pengertiannya hisbah dapat bermakna pengawasan, pengiraan dan penghitungan. Hisbah juga merupakan salah satu lembaga peradilan dalam Islam yang khusus menangani kasus moral dan berbagai bentuk maksiat, tetapi tidak memiliki wewenang peradilan. Sedangkan menurut Qanun Aceh, definisi Wilayatul Hisbah adalah badan yang bertugas mengawasi pelaksanaan Syariat Islam, atau lembaga untuk mengingatkan, membimbing dan menasehati. Kasus pelanggaran terhadap Qanun yang diserahkan kepada penyidik untuk diusut dan diteruskan ke pengadilan, merupakan kasus pelanggaran yang sudah melalui proses, upaya peringatan, nasehat dan bimbingan terhadap pelaku pelanggaran (Murziqin, 2010: 18).

Adapun tugas Polisi Syariah atau Polisi Wilayatul Hisbah Provinsi Aceh berdasarkan Qanun Nomor 5 Tahun 2007 Pasal 203 yakni memeliharadan menyelenggarakan ketenteraman dan ketertiban umum, menegakkan Peraturan Daerah (Qanun), Peraturan Gubernur, Keputusan Gubernur, melakukan sosialisasi, pengawasan, pembinaan, penyidikan, dan pelaksanaan hukuman dalam lingkup peraturan perundangundangan di bidang Syariat Islam. Qanun-qanun yang terkait dengan ranah kewenangan Polisi Syariah antara lain:

1. Qanun Nomor 11 Tahun 2002 tentang pelaksanaan Syariat Islam bidang Aqidah, Ibadah dan Syiar Islam.

2. Qanun Nomor 12 Tahun 2003 tentang minuman Khamar (minuman keras) dan sejenisnya.

3. Qanun Nomor 13 Tahun 2003 tentang Maisir (perjudian).
4. Qanun Nomor 14 Tahun 2003 tentang Khalwat (mesum).

5. Qanun Nomor 7 Tahun 2004 tentang Pengelolaan Zakat.

6. Qanun Nomor 7 Tahun 2013 tentang Hukum Acara Jinayat. ${ }^{7}$

Berdasarkan tugas yang disebutkan di atas, maka kewenangan Wilayatul Hisbah juga berkaitan dengan melakukan pengawasan terhadap pelaksanaan peraturan dan perundang-undangan di bidang Syariat Islam yakni menegur, menasehati, mencegah dan melarang setiap orang yang patut diduga telah, sedang atau akan melakukan pelanggaran terhadap peraturan perundang-undangan di bidang Syariat Islam. Untuk mewujudkan hal tersebut, maka Wilayatul Hisbah juga harus bekerja sama dengan lembaga-lembaga penegak hukum lainnya seperti Kepolisian, Kejaksaan, Mahkamah Syariah dan lembaga terkait lainnya yang ada di wilayah Pemerintah Aceh (Murziqin, 2010: 31-2).

Terkait dengan struktur, sebelumnya telah disebutkan bahwa Wilayatul Hisbah sebagai bagian dari Satuan Polisi Pamong Praja. Pemerintah Pusat melalui Undang-Undang Nomor 11 Tahun 2006 tentang Pemerintahan Aceh, pada Pasal 244 telah menyebutkan ketentuan tersebut. Penggabungkan Satuan Polisi Pamong Praja dengan Wilayatul Hisbah menjadi satu kesatuan dalam Satuan Kerja Pemerintahan Aceh (SKPA) telah menguatkan peran Polisi Syariah secara legalitas hukum dalam legitimasi perundang-undangan di Indonesia. Dengan demikian Polisi Syariah Aceh menjadi bagian dari aktor-aktor keamanan di daerah, bersama dengan Satuan Polisi Pamong Praja (Satpol

\footnotetext{
Sebagai Qanun baru yang disahkan pada 27 September 2014, Qanun Nomor 7 Tahun 2013 tentang Hukum Acara Jinayat ini ketika mulai berlaku (setahun setelah diundangkan yakni 28 September 2015), maka Qanun tentang Khamar, Maisir, dan Khalwat akan dicabut dan dinyatakan tidak berlaku lagi. Qanun ini dirangkum dan dilengkapi berdasarkan dari Qanun-Qanun sebelumnya.
} 
PP), Kepolisian, Komando Teritorial TNI dan Komunitas Intelejen Daerah (Kominda).

Fungsi pemolisian (policing function) Satpol PP dan Polisi Syariah, pada kedudukannya adalah sama, yang menjadi perbedaan utama terletak pada kasus yang menjadi kewenangannya. Satuan Polisi Pamong Praja dan Polisi Wilayatul Hisbah adalah lembaga penegak hukum yang melaksanakan tugas kepala daerah dan bertanggung jawab kepada kepala daerah melalui sekretaris daerah. Namun, Satpol PP dan Polisi Syariah memiliki kewenangan pada ranah yang berbeda, apabila Satpol PP pada penegakan Peraturan Daerah dan Keputusan Kepala Daerah secara umum, maka Polisi Syariah berwenang untuk menegakkan Qanun-Qanun Syariat Islam.

Dalam konsep policing function, seperti yang telah disebutkan di awal tulisan, bahwa fungsi pemolisian dalam tradisi community policing adalah membatu kerja-kerja pemolisian yang dilakukan oleh polisi (Polri), namun tidak sampai pada proses pengadilan, dan lebih cenderung mengawasi dan mencegah kemungkinan adanya gangguan keamanan dan ketertiban. Kasus Polisi Syariah, menjelaskan sebagian dari hal tersebut, sementara sebagian yang lain bertolak belakang dengan konsep tersebut. Apabila kita mengaitkan keseluruhan uraian diatas dengan konsep dari policing - baik itu paradigma keamanan ataupun policing function - dapat kita simpulkan bahwa keberadaan Polisi Syariah di Aceh merupakan kepentingan negara dalam mempertahankan rezim. Dengan melihat implementasi dan reaksi di lapangan adalah jawaban dari pernyataan tersebut.

\section{Antara Qanun, Gender dan HAM}

Kepentingan negara-menyempurnakan ketentuan otonomi khusus Aceh - sangat jelas dalam regulasi-regulasi yang telah dibuat tentang Polisi Syariah. Hal ini juga dapat kita lihat dari kesimpulan Edward Aspinall, bahwa untuk meminimalisasi konflik di Aceh, pemerintah pusat memberikan otonomi khusus menyangkut penerapan Syariat Islam (Aspinall, 2005: 4). Akan tetapi, penyelesaian konflik ini menggunakan pendekatan state-centred, karena resolusi tersebut digunakan untuk mencegah disintegrasi bangsa. Sehingga Syariat Islam digunakan hanyalah sebagai instrumen, dan Polisi Syariah sebagai pelengkap dari instrumen tersebut.

Pendekatan state-centred terhadap penyelesaian konflik ternyata memicu konflik vertikal disisi lain. Dalam implementasi di masyarakat, gerakan perlawanan akan kita temukan dibalik kehadiran Polisi Syariah. Beberapa implementasi dari kinerja lembaga ini disinyalir telah melanggar HAM dan cenderung tebang pilih. Dimulai dari kesiapan perangkat negara hingga kesiapan masyarakat dengan perubahan sosial - penerapan Syariat Islam yang terjadi, menyebabkan ketegangan sosial di Aceh. Negara dan masyarakat hanyalah mempertontonkan hipokrisi terhadap konsep Syariat Islam.

Di ranah negara, salah satu peneliti Aceh, Ramzi Murziqin mengatakan bahwa ada banyak hal terkait Polisi Syariah yang bermasalah. ${ }^{8}$ Pertama, perekrutan anggota Polisi Syariah di beberapa kabupaten yang tidak selektif - tidak memiliki pemahaman Islam yang baik. Kedua, Polisi Syariah juga tidak memiliki "taring yang kuat", misalnya anggaran yang diberikan ke Polisi Syariah sangat sedikit. Menurut Ramzi Murziqin, paling tidak yang dapat disimpulkan saat ini mengenai Polisi Syariah bahwa Pemerintah Aceh terkesan tidak memiliki komitmen tinggi dalam pengimplementasian penerapan Syariat Islam; telah banyak kalangan yang tidak lagi mengharapkan kehadiran Polisi Syariah; dan wibawa Polisi Syariah di mata masyarakat pun negatif. Pada kesimpulannya, Polisi Syariah dibentuk sepenuh hati tetapi dalam

8 Wawancara dilakukan melalui email antara tanggal 28 Desember 2013 - 2 Januari 2014. 
implementasi, Polisi Syariah diperhatikan setengah hati.

Hal lain yang kontraproduktif adalah persoalan gender. Keberadaan Polisi Syariah baik secara hukum maupun tindakannya di lapangan menuai berbagai protes, salah satunya dari Human Rights Watch (HRW). Berdasarkan hasil dari penelitian Human Rights Watch (2010) di Banda Aceh, Bireuen, Lhokseumawe, Langsa dan Meulaboh, Aceh, dan Jakarta menyebutkan bahwa dalam beberapa kasus yang diinvestigasi, ditemukan bahwa proses penghakiman terhadap pelaku pelanggaran Qanun Syariat Islam berdasarkan pada standar yang sewenangwenang. Misalnya, masyarakat memberikan perlakuan yang kasar dan memalukan selama proses penangkapan, beberapa dari mereka yang dituduh diharuskan membayar ganti rugi yang tinggi atau menjalani hukuman lain berupa kawin paksa atau pengusiran dari desa. Selain itu, sebagian besar dari kasus yang terjadi dalam laporan penelitian tersebut berkaitan dengan perempuan. Hal senada juga disimpulkan oleh Komnas Perempuan yang telah berulang kali memberi peringatan bahwa cara syariah yang diterapkan di Aceh memfasilitasi terjadinya sejumlah pelanggaran (Human Rights Watch, 2010: 2). HRW dan Komnas Perempuan dalam berbagai laporannya menyoroti Qanun tentang syariah yang berkaitan dengan Khalwat dan Busana Islami yang menurut lembaga ini, konsep dan praktik hukum tersebut sangat bias gender. Beberapa kasus lain terkait Qanun yang bias gender cukup banyak ditemukan. Yang terbaru antara lain: pada bulan Januari 2013 walikota Lhokseumawe di provinsi Aceh melarang perempuan mengangkangi sepeda motor atas nama Syariah; pada bulan Mei 2013 Bupati Bireuen melarang perempuan menari di tempat umum; di Meulaboh, pemerintah daerah telah membatasi perempuan untuk mengenakan rok sejak 2012 (Harsono, 2014). Berbagai peraturan yang bias gender tersebut berujung pada menciptakan keamanan dan ketertiban jika kemudian Qanun tersebut dilanggar oleh perempuan Aceh. Di sini, implementasi keamanan kemudian bertentangan dengan paradigma human security. Akhirnya, prinsip human security bahwa orang-orang hidup dalam masyarakat untuk beraktivitas dengan bebas dengan banyak pilihan tereduksi dengan hadirnya Qanun di Aceh.

Komnas Perempuan mencatat sampai tahun 2013 di Indonesia terdapat 342 kebijakan diskriminatif, sebanyak 265 diantaranya secara langsung menyasar kepada perempuan atas nama agama dan moralitas. ${ }^{9}$ Daerah-daerah lain di Indonesia sepertinya telah terinspirasi oleh Qanun Aceh untuk mengeluarkan perda-perda bernuansa syariah di daerahnya masing-masing. Beberapa komentar dari aktivis gerakan HAM terkait Qanun Syariah: menurut Elaine Pearson, wakil direktur untuk Asia Human Rights Watch, kedua peraturan Syariah (Qanun Nomor 11 Tahun 2002 tentang pelaksanaan Syariat Islam bidang Aqidah, Ibadah dan Syiar Islam dan Qanun Nomor 14 Tahun 2003 tentang Khalwat) telah melanggar hak-hak masyarakat untuk membuat keputusan sendiri mengenai siapa yang harus mereka temui dan apa yang mereka kenakan. Sementara itu, Phelim Kine mengatakan penerapan Syariat Islam di Aceh tidak memenuhi standar internasional, salah satunya dengan penerbitan Qanun baru (Qanun Nomor 7 Tahun 2013 tentang Hukum Acara Jinayat) disahkan pada September 2014 yang mengikat warga non-Muslim, peminum alkohol, dan kaum homoseksual, serta semua pihak yang memiliki hubungan di luar nikah. ${ }^{10}$ Kritik dari HRW tersebut merujuk pada Kovenan Internasional Perserikatan Bangsa-Bangsa tentang Hak Sipil, Politik, Ekonomi, Sosial, dan Budaya. Pada gilirannya HRW menganggap Qanun ini adalah tindakan diskriminasi terhadap jenis kelamin,

\footnotetext{
9 www.voaindonesia.com

${ }^{10}$ http://www.rappler.com/world/regions/asia-pacific/ indonesia/84749-kontroversi-syariat-islam-di-aceh.
} 
agama, politik, asal usul kebangsaan atau status lainnya.

Dalam praktiknya, Polisi Syariah juga telah membangun stigma berupa ketidakpercayaan pada institusi ini yang hanya mengatur dan memberikan bimbingan kepada masyarakat kelas bawah saja, sedangkan kepada masyarakat kelas menengah ke atas dan kepada elit (pelaksana negara) luput (Human Right Watch, 2010: 4). ${ }^{11}$ Akibatnya, seringkali terjadi pembangkangan langsung di lapangan (kontak fisik) antara personil Polisi Syariah dan masyarakat. ${ }^{12}$ Seorang warga Aceh juga menyatakan bahwa kehadiran Polisi Syariah terkesan pilih kasih, dia memberi contoh ada seorang pejabat yang juga tokoh masyarakat di Banda Aceh ditangkap Polisi Syariah saat sedang berbuat mesum, tetapi tidak pernah diadili:

"Jangan seperti selama ini, syariat Islam terkesan hanya berlaku untuk rakyat jelata, sementara para pejabat yang melanggar syariat Islam tidak pernah diproses hukum dan tak dicambuk". ${ }^{13}$

Meyimpulkan keseluruhan realita diatas, kalau kita menggunakan tipologi policing function (Hiariej et al., 2013) yang berdasarkan perdebatan paradigma national security dengan human security atau state-centred dengan peoplecentred, ditemukan kontadiksi dalam kasus Polisi Syariah. Disatu sisi lembaga ini menggunakan konsep community policing yang dikenal dalam human security, namun disisi lain, lembaga ini menggunakan logika state oriented dalam paradigma pemolisiannya. Kebutuhan untuk menyempurnakan kewenangan yang diberikan melalui Otonomi Khusus, kemungkinan besar menjadi salah satu determinan untuk menciptakan lembaga ini, yang berfungsi

\footnotetext{
${ }^{11}$ Hal senada juga disampaikan Ramzi Murziqin.

${ }^{12}$ Ramzi Murziqin, wawancara dilakukan melalui email antara tanggal 28 Desember 2013 - 2 Januari 2014.

${ }^{13}$ www.rappler.com.
}

dalam ranah keamanan dan ketertiban di masyarakat Aceh. ${ }^{14}$ Akibatnya, pemaknaan policing function melalui praktik community policing dirasakan oleh sebagian masyarakat sebagai bentuk diskriminasi, bias gender, dan pelanggaran atas hak asasi manusia.

\section{Kesimpulan}

Kehadiran Polisi Syariah telah membangun tesis bahwa policing function di Indonesia merupakan sesuatu yang sulit, kompleks, dan bermasalah, tetapi penting bagi keberlangsungan hidup demokrasi. Tuntutan demokrasi melalui wajah desentralisasi dengan wujud implementasi otonomi khusus secara tidak langsung berbenturan dengan tuntutan human security. Kekuatan nilai lokalitas telah mengajak kita untuk mendiskusikan kembali konsepsi keamanan yang selama ini cenderung untuk dipaksakan setara dan sama secara global. Sementara agama dan adat adalah konsep penegakan hukum yang dipahami dan dijunjung tinggi dalam masyarakat lokal, meskipun dapat dimanipulasi untuk kepentingan rezim di daerah.

Disisi lain, bentuk community policing yang ada merupakan interaksi substansial antara karakteristik masyarakat dan bagaimana cara hal itu diawasi. Terdapat variasi secara "alamiah" (indigenous) sebagai karakteristik masyarakat, yang berasal dari nilai (agama dan adat). Ada juga variasi dalam keputusan yang dibuat oleh pemerintah (rezim) yang memengaruhi karakteristik pemolisian dalam kasus Polisi Syariah. Dari dua hal inilah keamanan ditujukan. Oleh karena itu, penulis menyebut kasus ini sebagai indigenously policing. Kalaupun dianalisis lebih jauh, antara paradigma dan aktualisasi dari Polisi Syariah,

\footnotetext{
${ }^{14}$ Para perwakilan GAM pada awalnya mengkritik dengan keras adanya hukum Syariah, dan menyebutnya sebagai "muslihat" yang bertujuan untuk menyesatkan masyarakat Aceh dan pihak berwenang dalam agama untuk mendukung Pemerintah yang didukung oleh Jakarta (Edward Aspinall dikutip dalam Human Rights Watch, 2010: 17).
} 
dapat disimpulkan bahwa dua hal tersebut tidak bersinergi. Dibutuhkan studi yang lebih spesifik kedepannya untuk menemukan dualisme pemolisian dan kontrol sosial dalam kasus Polisi Syariah, serta isu-isu politik dan kelas yang terkait dalam penegakan Syariat Islam di Aceh. Sebagai kesimpulan awal, Aceh adalah sebuah simbiosis dan konsensus antara "negara Islam" dan "Islam populer" untuk menjelaskan lembaga Polisi Syariah dalam proses penegakan hukum Syariah. Singkatnya, keamanan dalam masyarakat Aceh sangat mengakar kuat dalam sejarah dan politiknya, yang keberadaannya saat ini tergantung pada banyak toleransi dan pengertian.

Berdasarkan kategorisasi literaturliteratur dalam human security, dapat kita simpulkan bahwa konsep keamanan ditujukan sebagai bagian keamanan individu dari segala ancaman yang sifatnya people-centred, yang menuntut kebebasan dari rasa takut dan kebebasan berekspresi sebagai individu. Sebaliknya, Polisi Syariah adalah ide yang mengutamakan kepentingan ummat - atau paling tidak menghilangkan kebebasan individu - dalam sebuah tujuan keamanan dan ketertiban sosial di masyarakat dari ancaman yang sifatnya state-centred untuk perwujudan kepentingan rezim. Realita ini tentunya bertolak belakang dengan konsep human security seperti yang telah diuraikan sebelumnya, begitupun dengan fungsi community policing.

Pada tataran teoretis, kehadiran Polisi Syariah menyebabkan community policing menjadi salah satu fitur penting dari studi kepolisian kontemporer yang bergerak pada konsep state-centred, yang makna dan implementasinya bervariasi tergantung di mana kita berada dan dengan siapa kita berbicara. Paradigma yang muncul dari pembentukan Polisi Syariah mungkin tampak begitu asing dan begitu moralis, bahwa kita melewatkan penilaian mendasar dari nilai-nilai keamanan dalam tradisi konseptual human security yang menuntut kebebasan dari rasa takut, bebas mengaktualisasikan keinginan dan kebebasan untuk hidup bermartabat. Akan tetapi, fenomena ini, dapat membuat perbedaan besar dalam cara kita berpikir, mempraktekkan, dan mempromosikan arti indigenously policing bagi studi keamanan. Misalnya, bagi negaranegara transisi demokrasi, berbicara keamanan adalah membicarakan stabilitas negara, dimana post-authoritarianism telah menjadikan pola kebijakan keamanan akan sangat cenderung pada state-oriented - bagaimana negara ini tidak berantakan. Nilai-nilai lokalitas pun menjadi cara untuk mengatasi ketakutan terhadap ancaman keamanan negara yang sifatnya dari dalam negara itu sendiri.

Masa depan indigenously policing memerlukan penelitian lebih lanjut mengenai kompleksitas fenomena tersebut secara global. Mengingat bahwa studi terbaru tentang Aceh menyebutkan sistem syariah telah berusaha untuk menggunakan hukum Islam dan lembagalembaga hukum didalamnya sebagai alat untuk mengarahkan masyarakat pada arah tertentu yang diinginkan, dimana Syariat Islam di Aceh adalah "as projects for future-oriented social transformation" dalam masyarakat Islam kontemporer (Feener, 2012, 2013). Selain itu, dalam proyeksi terbaru oleh PEW Forum on Religion and Public Life (PEW Research Center) tahun 2012, penduduk Islam diperkirakan tumbuh sekitar dua kali tingkat populasi agama lain selama dua dekade berikutnya, naik sekitar 26,4 persen dari total masyarakat dunia, dan diproyeksikan populasinya berjumlah 8,3 miliar pada tahun 2030 (Hakeem et al., 2012: 6). ${ }^{15}$ Ditambah lagi, dimulai dengan konflik etnis dan agama di banyak negara Muslim, ditambah peristiwa 11 September memberikan alasan bagaimana agama - khususnya Islam - memainkan peran penting sebagai faktor ideasional dalam upaya berkelanjutan untuk menjelaskan keamanan dunia (Othman, 2007:3).

\footnotetext{
${ }^{15}$ Data ini dapat dilihat pada The future of the global Muslim population (http://pewforum.org/The-Futureof-the-Global-Muslim-Population.aspx)
} 
Pada akhirnya berdasarkan realita ini, kita tidak dapat mengabaikan pentingnya hal tersebut, dan pengaruhnya terhadap paradigma keamanan, yang sangat mungkin akan digunakan oleh masyarakat Islam di berbagai belahan dunia di masa mendatang.

\section{Daftar Pustaka}

Aspinall, E. (2005). Aceh/Indonesia: Conflict Analysis and Options for Systematic Conflict Transformation. (Prepared for the Berghof Foundation for Peace Support). Berghof Foundation for Peace Support.

Effendy, B. (2011). Islam dan Negara: Transformasi Gagasan dan Praktik Politik Islam di Indonesia. Jakarta: Yayasan Abad Demokrasi.

Feener, R. M. (2012). Social Engineering through Sharia: Islamic Law and State-Directed $D a^{\prime} w a$ in Contemporary Aceh. Islamic Law and Society 19 (2012), pp. 275-311.

Feener, R. M. (2013). Shari'a and Social Engineering: The Implementation of Islamic Law in Contemporary Aceh, Indonesia. Oxford: Oxford University Press.

Garba, A. S. (2013). The Place of Community Policing under The Sharia'h and The Advent of Hisbah. (Online), (http://www.gamji. com/article6000/NEWS6178.htm, diakses 22 Desember 2013)

Hakeem, F. B., M. R. Haberfeld \& A. Verma (2012). Policing Muslim Communities: Comparative International Context. New York: Springer.

Harsono, A. (2014). Indonesian Women's Rights under Siege. (Online), (http://www.hrw.org/ news/2014/11/25/indonesian-women-srights-under-siege, diakses 25 Maret 2015).

Hasjmy, A. (1983). Kebudayaan Aceh dalam Sejarah. Jakarta: Beuna.

Hiariej, E., C. Lay \& E. Endaryanto (2012). Reformasi Sektor Keamanan. Bahan ajar mata kuliah Politik Keamanan dan Pembangunan. Jurusan Politik Pemerintahan, Fisipol, Universitas Gadjah Mada.

Human Rights Watch (2010). Menegakkan Moralitas: Pelanggaran dalam Penerapan
Syariah di Aceh, Indonesia. Laporan Penelitian. (Online), (http://www.hrw.org/node/94471, diakses 7 Maret 2015)

Human Rights Watch (2010). Indonesia: Peraturan Daerah Syariah Melanggar Hak Asasi di Aceh (Online), (http://www.hrw. org/news/2010/11/29/indonesia-peraturandaerah-syariah-melanggar-hak-asasi-diaceh, diakses 7 Maret 2015).

Imarah, M. (1999). Islam dan Keamanan Sosial. Jakarta: Gema Insani Press.

Ismuha (1983). “Ulama Aceh dalam Perspektif Sejarah", dalam Taufik Abdullah (ed) Islam dan Perubahan Sosial. Jakarta: CV Rajawali - YIIS.

Murziqin, R. (2010). Dampak Penggabungan Satuan Polisi Pamong Praja dengan Wilayatul Hisbah terhadap Penegakan Syariat Islam di Aceh. Skripsi Fakultas Syari'ah, Institut Agama Islam Negeri Ar Raniry Darussalam. Banda Aceh: tidak diterbitkan.

Nicholl, C. G. (1999). Community policing, Community Justice, and Restorative Justice: Exploring the Links for the Delivery of a Balanced Approach to Public Safety. Washington, DC: U.S. Department of Justice, Office of Community Oriented Policing Services.

Olaniyi, R. O. (2011). Hisbah and Sharia Law Enforcement in Metropolitan KaNomor Africa Today, Summer 2011, Vol. 57 Issue 4, pp. 71-96.

Othman, Z. (2007). Human Security In Islam. Makalah yang dipresentasikan dalam International Development Studies Conference, "Mainstreaming Human Security: The Asian Contribution" di Bangkok, Thailand, 4-5 Oktober 2007.

Othman, Z. (2009) “Human Security Concepts, Approaches and Debates in Southeast Asia" dalam Hans Günter Brauch et al. (Eds.) Facing Global Environmental Change: Environmental, Human, Energy, Food, Health and Water Security Concepts. Berlin: Springer. 
Paris, R. (2001). Human security: Paradigm Shift or Hot Air? International Security, Vol. 26, Nomor 2 (Fall 2001), pp. 87-102.

Qanun Aceh Nomor 5 Tahun 2007 Tentang Susunan Organisasi dan Tata Kerja Dinas, Lembaga Teknis Daerah, dan Lembaga Daerah Provinsi Nanggroe Aceh Darussalam.

Rappler. (2015). Syariat Islam di Aceh: HRW sebut penerapannya langgar HAM (Online), (http. rappler.com/world/regions/asia-pacific/ indonesia/84749-kontroversi-syariat-islamdi-aceh, diakses 11 Maret 2015).

Saleh, H. (1992). Mengapa Aceh Bergolak. Jakarta: Grafiti.

Sherman, L. W. (1984). Policing Communities: What Works? Crime and Justice, Vol. 8, Communities and Crime, pp. 343-386.

Shinoda, H. (2004). The Concept of Human security: Historical and Theoretical Implications. IPSHU English Research Report Series Nomor19, Conflict and Human security: A Search for New Approachesof Peace-building.

Siboro, T. (ed.) (2008). Police Reform: Taking the Heart and Mind. Jakarta: Propatria Institute.
Sindre, G. M. (2011). “Dari Perlawanan Senjata Menuju Partisipasi Politik: Transformasi Politik GAM" dalam O. Tornquist, S. A Prasetyo \& T. Birks (eds) Aceh: Peran Demokrasi bagi Perdamaian dan Rekonstruksi. Yogyakarta: PCD Press.

Sufi, R. \& A. B. Wibowo (2006). Adat dan Islam di Aceh. Banda Aceh: Badan Perpustakaan Provinsi Nangroe Aceh Darussalam.

UNDP (1994). Human Development Report (cetakan ke-9). New York: Oxford University Press.

UU Nomor 11 Tahun 2006 tentang Pemerintahan Aceh.

Voa Indonesia (2013). Komnas Perempuan: Ada 342 Perda Diskriminatif di Indonesia. (Online), (http://www.voaindonesia.com/ content/komnas-perempuan-ada-342perda-diskriminatif-di-indonesia/1736465. html, diakses 11 Maret 2015).

\section{Wawancara:}

Ramzi Murziqin (Peneliti Polisi Syariah Aceh), wawancara melalui email pada tanggal 28 Desember 2013 - 2 Januari 2014. 